\title{
PERANCANGAN SISTEM APLIKASI INFORMASI TRANSAKSI PHOTOGRAPHY ACCESSORIES BERBASIS JAVA PADA STUDIO TAMAN MINI
}

\author{
Himawan \\ Program Studi Informatika, Fakultas Teknik dan Ilmu Komputer, Universitas Indraprasta PGRI \\ Jalan Raya Tengah No 80, Kelurahan Gedong, Pasar Rebo, Jakarta Timur \\ Himawan1106@gmail.com
}

\begin{abstract}
Abstrak
Tujuan dari penelitian ini adalah merancang sebuah sistem aplikasi informasi dan transaksi photography accessories yang efektif dan efisien. Metode pengumpulan data yang digunakan dalam penelitian ini adalah studi literatur dan wawancara. Hasil dari penelitian ini adalah Aplikasi Informasi dan transaksi yang dapat memudahkan bagian kasir dalam pengecekan data stok barang dan pembelian barang agar pekerjaan pengelolaan informasi dan transaksi photography accessories menjadi lebih efektif dan efisien. Selain itu aplikasi ini juga dapat mempermudah pekerjaan bagian kasir untuk dapat menyelesaikan pekerjaan dalam menyimpan data dengan cepat dan akurat guna mengefisienkan waktu pekerjaan.
\end{abstract}

Kata Kunci : Perancangan, Aplikasi, Transaksi, Java

\begin{abstract}
The purpose of this research is to design an information application system and transaction of effective and efficient photography accessories. The data collection methods used in this research were literature research and interviews. The result of this research is the information application and transactions that can facilitate the cashier in the checking of stock data of goods and the purchase of goods so that the work of information management and transaction of photography accessories is more effective and efficient It can also simplify the job of the cashier to get the job done in storing data quickly and accurately to streamline job time.
\end{abstract}

Keyword : Design, Application, Transactions, Java

\section{PENDAHULUAN}

Pada masa ini perkembangan teknologi dan komputer tumbuh dengan sangat pesat terutama pada bidang komputer. Komputer tidak hanya digunakan sebagai alat untuk mencari informasi, namun juga dapat digunakan untuk mengolah suatu data yang dapat berguna bagi perkembangan komputer itu sendiri dan manusia yang menggunakannya. Pada saat ini banyak pekerjaan yang dilakukan dengan cara manual dapat digantikan oleh komputer yang dapat mempersingkat waktu pengambilan informasi. Bukan hanya itu, komputer juga dapat bekerja secara akurat, cepat dan tepat.

Seperti halnya pada Studio Foto Taman Mini dalam hal pengelolaan data transaksi penjualan masih dilakukan secara manual, hal tersebut sering menimbulkan beberapa permasalahan. Oleh karena itu perlu adanya suatu sistem yang tepat dan terkomputerisasi pada Studio Foto Taman Mini khususnya dalam informasi ketersediaan barang, transaksi dan pembuatan laporan, dapat membantu pihak manajemen dalam pengelolaan data-data pelanggan secara efesien. (Subhan, 2012) dalam bukunya yang berjudul Analisa Perancangan Sistem mendefinisikan pengertian dari sistem sebagai berikut: "Suatu sistem dapat diartikan sebagai suatu kumpulan atau himpunan dari unsur, komponen, atau variabel-variabel yang terorganisasi, saling berinteraksi, saling tergantung satu sama lain dan terpadu. Sistem juga merupakan kumpulan elemen-elemen saling terkait dan bekerja sama untuk memproses masukan (input) yang ditujukan kepada sistem tersebut dan mengolah masukan tersebut sampai menghasilkan keluaran (output) yang diinginkan".Serta pengertian dari Yakub (Yakub, 2012) dalam bukunya yang berjudul Pengantar Sistem Informasi mendefiniskan sistem adalah: "Sekelompok elemen-elemen yang terintegrasi dengan tujuan yang sama untuk mencapai tujuan. Sistem juga merupakan suatu jaringan kerja dari prosedur-prosedur yang saling berhubungan, terkumpul bersama-sama untuk melakukan suatu kegiatan atau tujuan tertentu". Menurut (Sutabri, 2012) model umum sebuah sistem adalah input,proses, dan output. Hal ini merupakan konsep sebuah sistem yang sangat sederhana sebab sebuah sistem dapat mempunyai 
beberapa masukan dan keluaran. Selain itu dapat membantu semuanya menjadi terarah sehingga menjamin kelancaran proses kerja, mencegah adanya ketidakpuasan pelanggan, struktur organisasi yang terarah, lingkungan perusahaan lebih teratur dan memudahkan dalam pengendalian.

Adapun rumusan masalah pada penelitian ini adalah bagaimana membuat rancangan aplikasi informasi dan transaksi pada Studio Foto Taman Mini yang efektif dan efisien, bagaimana sistem ini dapat membantu proses pembuatan laporan penjualan, bagaimana sistem ini dapat memberikan informasi data data barang secara akurat. Sedangkan tujuan penelitian ini adalah merancang sebuah sistem aplikasi penjualan yang efektif dan efisien sesuai dengan kebutuhan pada Studio Foto Taman Mini. Perancangan adalah sebuah proses untuk mendefinisikan sesuatu yang akan dikerjakan dengan menggunakan teknik yang bervariasi serta didalamnya melibatkan deskripsi mengenai arsitektur serta detail komponen dan juga keterbatasan yang akan dialami dalam proses pengerjaannya (Rizky, 2011). Menurut (Presman, 2010), Perancangan adalah langkah pertama dalam fase pengembangan rekayasa produk atau sistem. Perancangan itu adalah proses penerapan berbagai teknik dan prinsip yang bertujuan untuk mendefinisikan sebuah peralatan, satu proses atau satu sistem secara detail yang membolehkan dilakukannya realisasi fisik.

Hasil dari penelitian ini adalah aplikasi informasi transaksi penjualan yang dapat memudahkan pegawai dalam melihat barang apa saja serta berapa jumlah barang yang tersedia, selain itu manfaat yang didapat dari penelitian ini adalah memberikan suatu tempat untuk bagian kasir yang bertugas untuk mengelola administrasi pada sistem aplikasi yang dibuat, sehingga semua transaksi dapat dilakukan dengan cepat dan akurat.

\section{PENELITIAN RELEVAN}

Penelitian oleh Nutul Azwanti (2017) dengan judul Sistem Informasi Penjualan Tas Berbasis Web. Hasil dari peneltian tersebut adalah Aplikasi yang dibuat berbasis website yang dapat memudahkan dalam proses pengolahan data penjualan tas pada tempat yang menjadi mitra, erta informasi yang didapatkan akan lebih akurat.

Penelitian oleh Tri Utami (2015) dengan judul Pembangunan Sistem Informasi Penjualan Obat pada Apotek Punung. Hasil dari peneltian tersebut adalah sistem informasi penjualan obat yang dapat meningkatkan efektifitas dalam memasukkan data obat dan mencari data obat sehingga dapat mempermudah dalam transaksi penjualan. Sistem informasi penjualan ini menyediakan beberapa fasilitias yang dapat digunakan oleh pengguna, meliputi :input data dan laporan.

\section{METODE PENELITIAN \\ Studi Literatur}

Pengumpulan data dan informasi yang dilakukan untuk perancangan aplikasi transaksi pembayaran di Studio Foto Taman Mini adalah dengan cara :

a. Mempelajari sistem dari aplikasi transaksi pembayaran lainnya.

b. Mempelajari buku-buku mengenai menganalisis dan mendesain sebuah sistem.

c. Mempelajari buku-buku pemograman Java dan $M y S Q L$.

d. Mempelajari dari jurnal-jurnal tentang penjualan.

\section{Interview (wawancara)}

Teknik mewawancarai ini dimulai dengan meminta izin kepada bapak Sukirman selaku pemilik usaha Studio Foto Taman Mini untuk melakukan penelitian dan bertanya langsung kepada pegawai yang bertugas sebagai kasir mengenai pengolahan data transaksi pembayaran guna mendapatkan informasi yang dibutuhkan dalam proses penelitian. Menurut hasil wawancara dengan pegawai bagian kasir, bahwasistem yang digunakan Studio Foto Taman Mini ini masih menggunakan cara manual, sehingga sering menyebabkan terhambatnya proses transaksi terhadap pelanggan dan menyebabkan pelayanan menjadi kurang efektif serta memakan banyak waktu.

\section{HASIL DAN PEMBAHASAN}

\section{Proses Bisnis Sistem Berjalan}

Proses Pendataaan Barang

a. Karyawan menyiapkan daftar barang yang akan dijual 
b. Pimpinan memenuhi kebutuhan yang diperlukan dalam proses penjualan barang yang akan dijual

Proses Pendataan Pesanan

a. Konsumen memesan pesanan pada karyawan

b. Karyawan menyiapkan pesanan konsumen

Proses Pendataan Pembayaran

a. Konsumen menerima pesanan yang telah dipesan

b. Konsumen membayar pesanan ke kasir

Proses Laporan

a. Kasir memberitahu pimpinan tentang persediaan sisa barang

b. Kasir membuat laporan data pembelian setiap akhir bulan

\section{Proses Bisnis Sistem Diusulkan \\ Diagram Konteks}

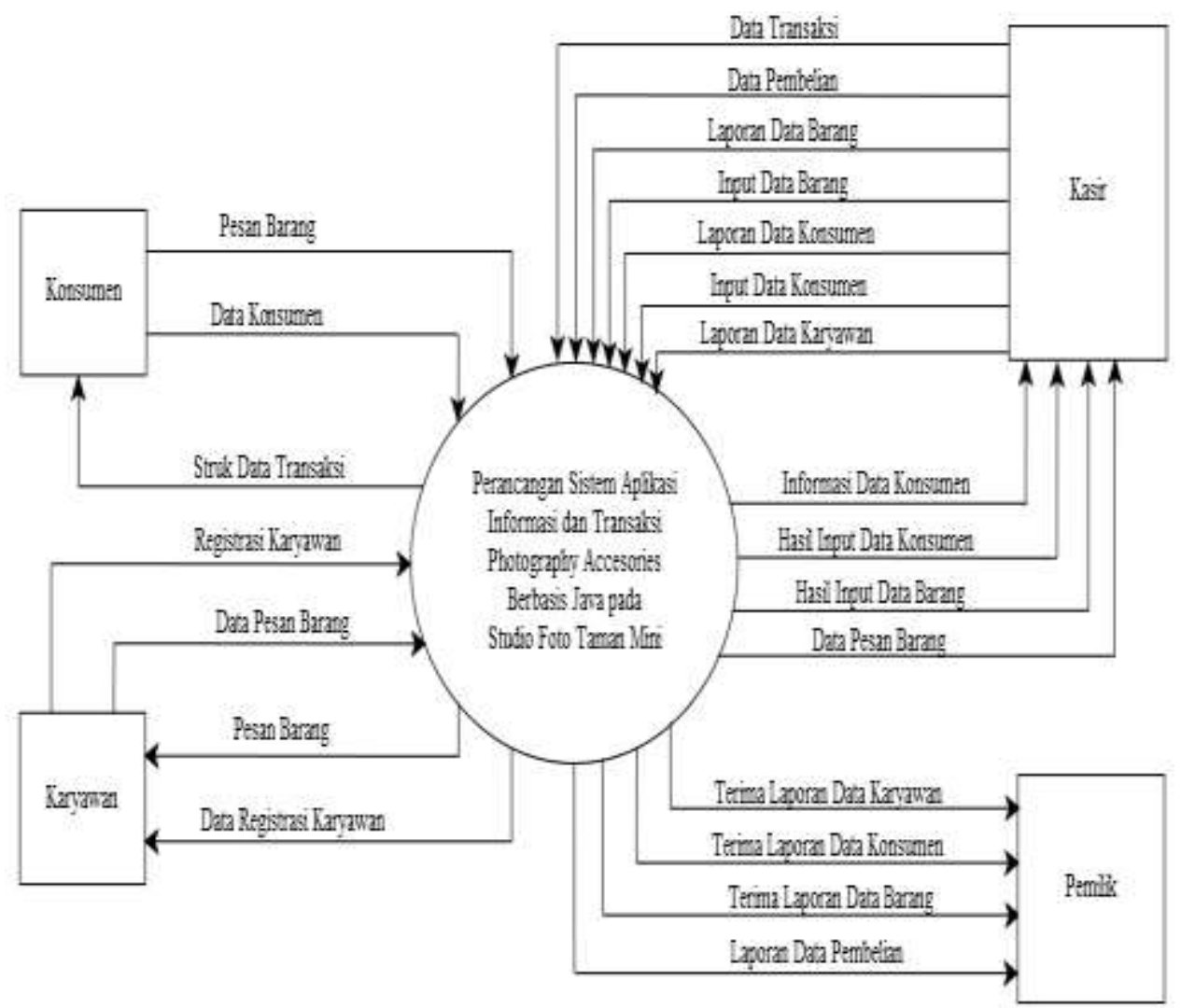

Gambar 1. Diagram Konteks

Merupakan gambaran keselurah sistem dari aplikasi perancangan sistem aplikasi informasi dan transaksi photography accessories berbasis java pada studio taman mini 


\section{Rancangan Basis Data Sistem \\ ERD (Entity Relationship Diagram)}

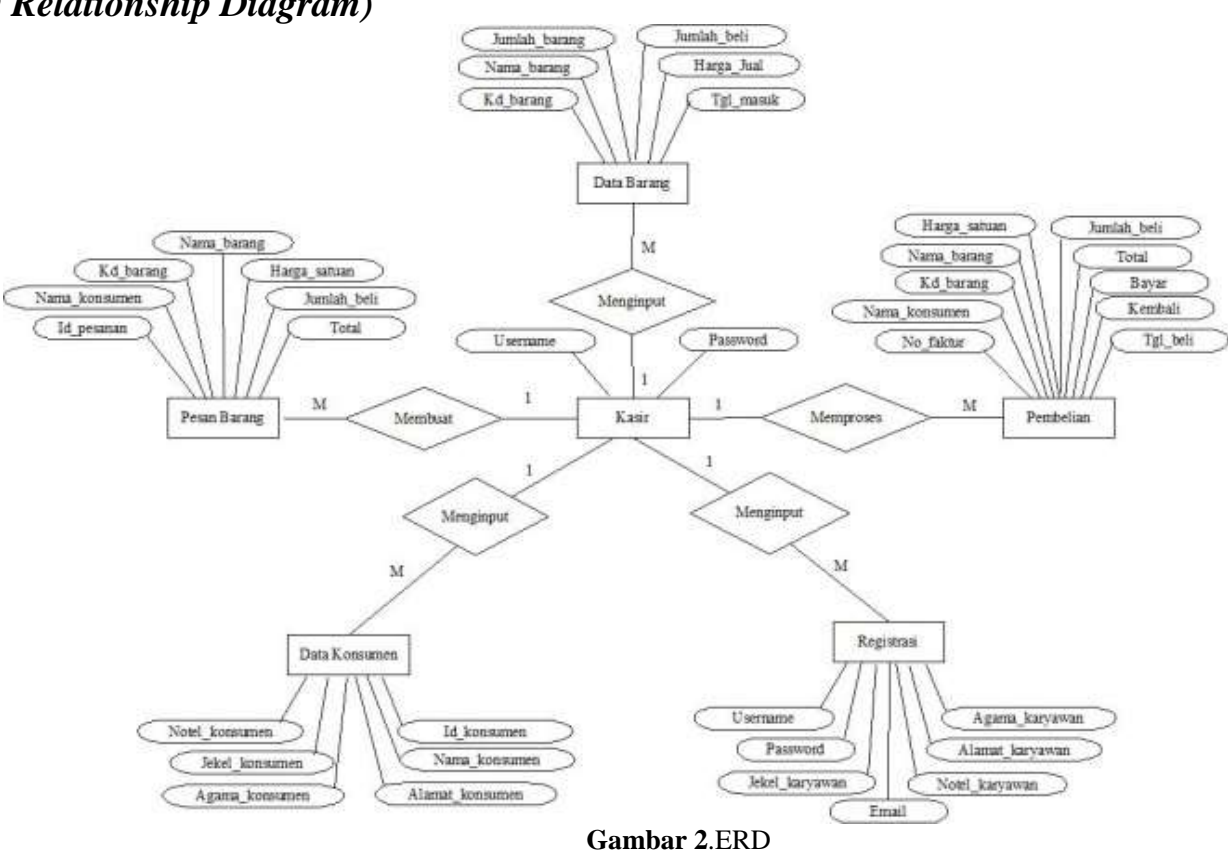

Merupakan sebuah diagram penjabaran database dalam aplikasi sebagai alur sistem aplikasi dan transaksi photography accessories berbasis java pada studio taman mini

\section{Tampilan Layar}

Berikut tahap implementasi dan pengujian pada software program yang telah di buat dengan bahasa pemprograman java.

\section{Tampilan Data Konsumen}

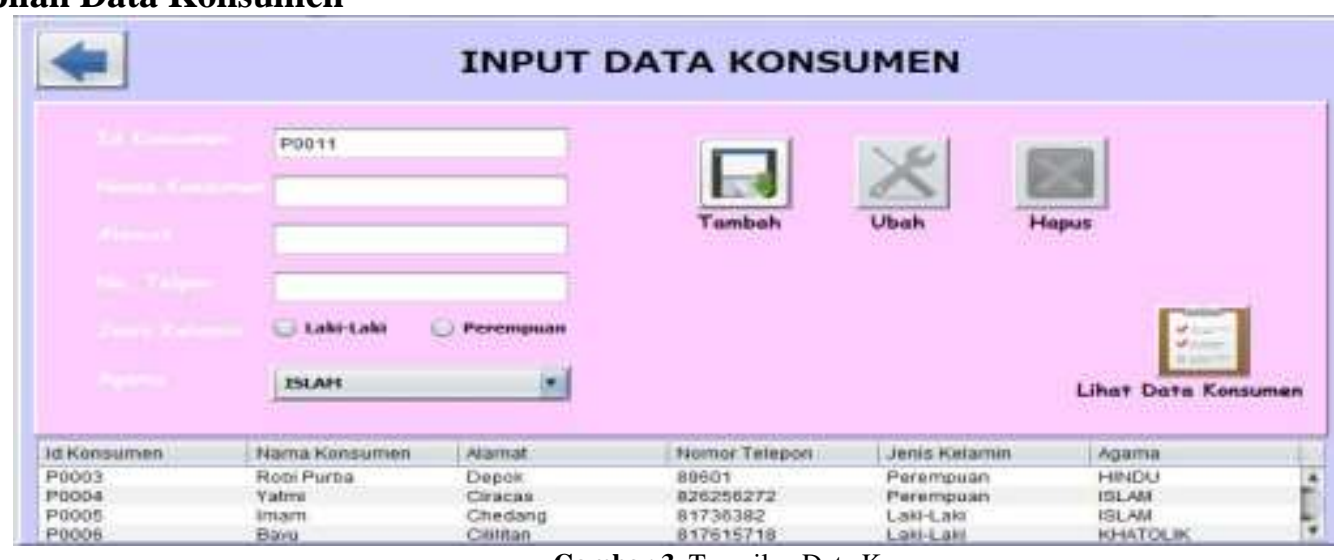

Tampilan ini merupakan tampilan untuk menyimpan data-data konsumen untuk disimpan dalam database yang berisikan Id Konsumen, Nama Konsumen, Alamat, Nomor Telepon, Jenis Kelamin, Agama 


\section{Tampilan Data Barang}

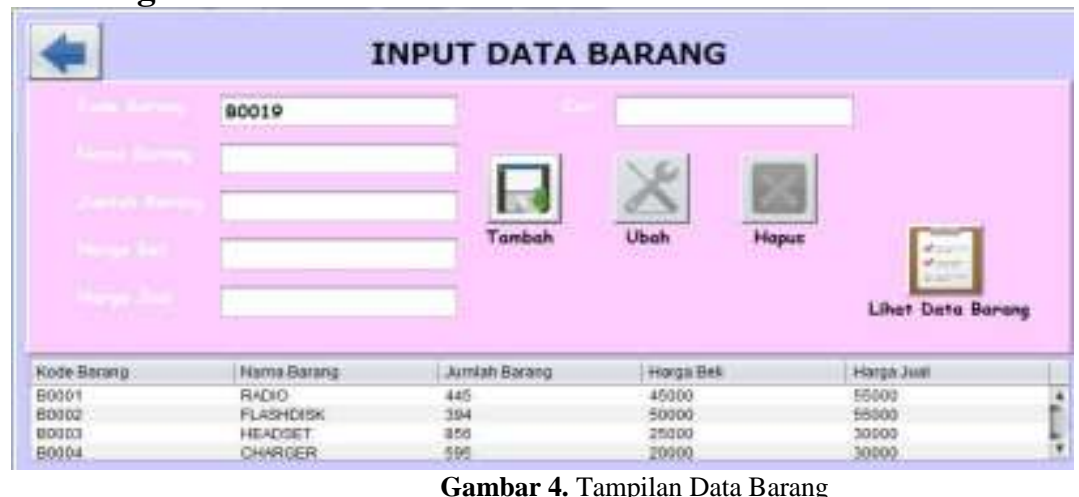

Tampilan ini merupakan tampilan untuk menyimpan data-data barang untuk disimpan dalam database yang berisikan Kode Barang, Nama Barang, Jenis Barang, Harga Beli, Harga Jual

\section{Tampilan Menu Transaksi}

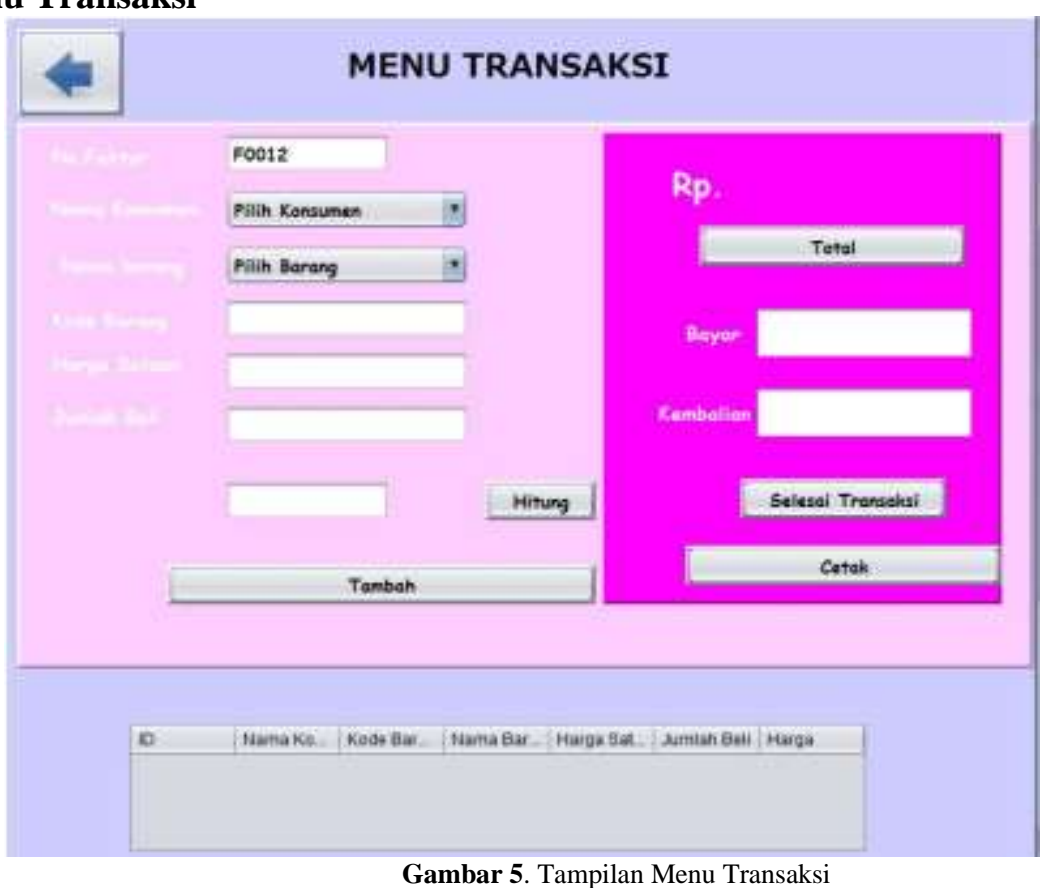

Tampilan ini merupakan tampilan untuk melakukan transaksi untuk disimpan dalam database yang berisikan No Faktur, Nama Konsumen, Nama Barang, Kode Barang, Harga Satuan, Jumlah Beli, Total, Bayar, Kembali 


\section{Tampilan Keluaran}

Laporan Data Karyawan

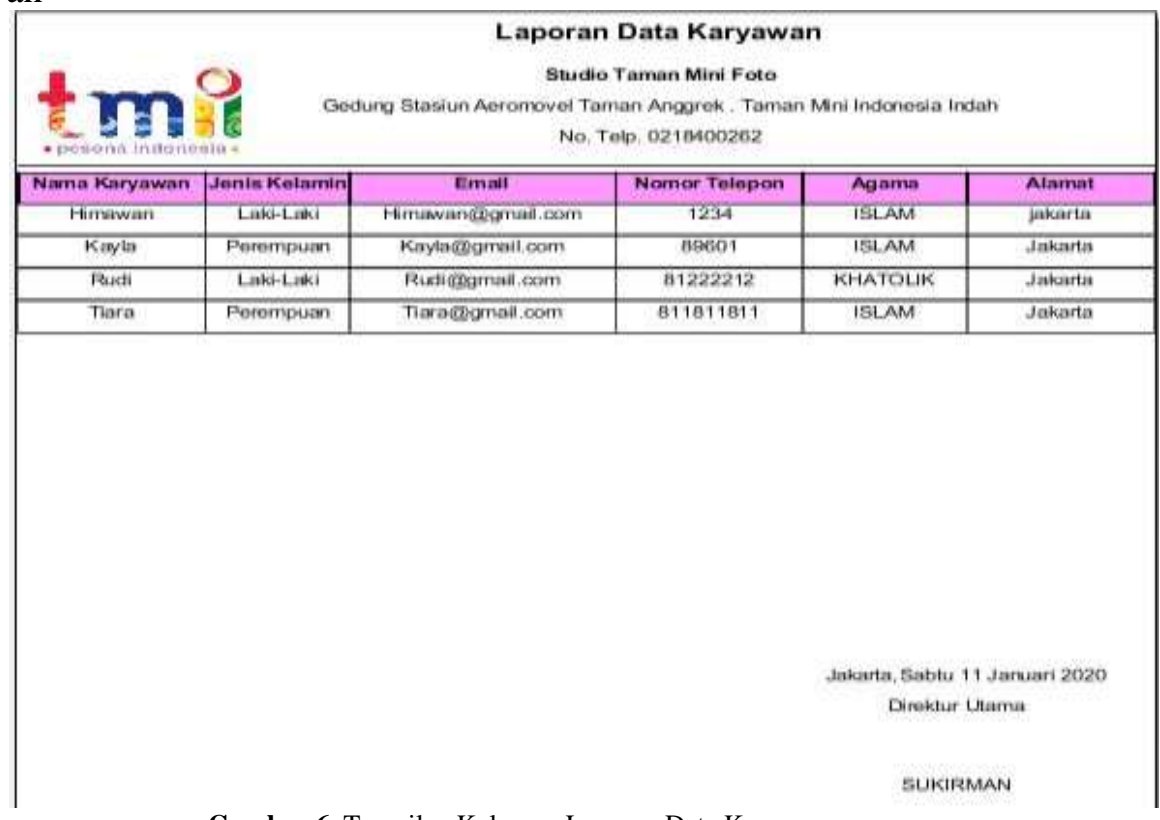

Gambar 6. Tampilan Keluaran Laporan Data Karyawan

Sebuah laporan data karyawan yang tersimpan di database yang dapat dicetak dan diserahkan kepada pemilik toko yang berisikan Nama Karyawan, Jenis Kelamin, Email, Nomor Telepon, Agama, Alamat.

\section{Laporan Data Konsumen}

\begin{tabular}{|c|c|c|c|c|c|}
\hline \multirow{2}{*}{ E. TE: } & \multicolumn{5}{|c|}{ 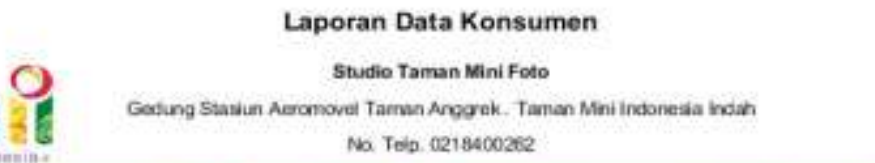 } \\
\hline & Narma Konswirman & Alamin & Namar Telepon & Jenis Kelesmin & Agama \\
\hline$P 0003$ & Ford Purtese & Depok & a9501 & Perempun & HINDU \\
\hline P0004 & $\begin{array}{l}\text { Yaleni } \\
\text { Yant }\end{array}$ & Cracest & 826256272 & Pernmpian & ISLAM. \\
\hline$P 0005$ & Imam & Credang & A1736382 & Laki-Laki & ISLAM \\
\hline P0000 & Esau. & Canton & 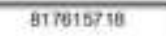 & Laki-Laki & KHWTOUK \\
\hline$P 000 ?$ & Choond & Cpasuno & $812 \pi 7270$ & Laki-Laki & ISLAM \\
\hline P0000 & Iwan & Cantan & 816715172 & Laki-Laki & ISLAM \\
\hline P0009 & Ans & Ragunan & 977 654332 & Porempun & ISLAM \\
\hline P0010 & $\mathrm{IKBML}$ & CELITAN & 97654332 & Laki-Laki & ISLAM \\
\hline & & & & $\begin{array}{l}\text { Wharta, Mingow } \\
\text { Drektir }\end{array}$ & anuat 2020 \\
\hline & & & & SUKIPA & \\
\hline
\end{tabular}

Gambar 7. Tampilan Keluaran Laporan Data Konsumen

Sebuah laporan data karyawan yang tersimpan di database yang dapat dicetak dan diserahkan kepada pemilik toko yang berisikan Laporan Data Konsumen : Id Konsumen, Nama Konsumen, Alamat, Nomor Telepon, Jenis Kelamin, Agama 


\section{SIMPULAN}

Secara garis besar, berdasarkan hasil Perancangan Sistem Aplikasi Informasi dan Transaksi Photography Accessories Berbasis Java pada Studio Foto Taman Mini yang telah dilakukan, dapat disimpulkan bahwa Dengan menggunakan sistem ini, maka: Proses transaksi penjualan akan dapat diorganisir dengan baik, Analisis dan pengujian program aplikasi informasi dan transaksi juga dapat berjalan dengan baik, Terdapat database sehingga mempermudah dalam pencarian data.

\section{DAFTAR PUSTAKA}

Presman, S. R. (2010). Rekayasa Peranggkat Lunak-buku, Pendekatan Praktisi (Edisi 7). Yogyakarta: Andi.

Rizky, S. (2011). Konsep Dasar Rekayasa Perangkat Lunak. Jakarta: Prestasi Pustaka.

Subhan, M. (2012). Analisa Perancangan Sistem. Jakarta: Lentera Ilmu Cendekia.

Sutabri, T. (2012). Analisis sistem informasi. Penerbit Andi.

Yakub, J. B. (2012). Pengantar Sistem Informasi. Graha Ilmu. 